\title{
SISTEM PENDUKUNG KEPUTUSAN PEMILIHAN LOKASI DAN EVALUASI LOKASI PEMASARAN PRODUK (GULA) MENGGUNAKAN METODE AHP (STUDI KASUS : PT.MADUBARU)
}

\author{
${ }^{\# 1}$ Riki Irawan (10018101), ${ }^{\# 2}$ Sri Winiarti (0516127501). \\ Program Studi Teknik Informatika Universitas Ahmad Dahlan \\ Jl. Prof. Dr. Soepomo, Telp. (0274) 379418 \\ Email : irawanriki50@yahoo.co.id ${ }^{1}$, sri.winiarti@ tif.uad.ac.id ${ }^{2}$
}

\begin{abstract}
Abstrak
PT. Madubaru yang berlokasi di Daerah Istimewa Yogyakarta bergerak di bidang agro industry dengan memiliki satu pabrik gula dan satu pabrik alkohol dan spiritus, yang dikenal dengan nama PG/PS Madukismo. PG/PS Madubaru di tuntut untuk dapat menciptakan kinerja pemasaran dan penjualan gula pasir yang handal. Dalam pemenuhan sasaran tersebut ada beberapa kendala yang dihadapi oleh perusahaan yaitu dalam proses penjualan gula pasir yang dilakukan tidak tercapai target yang diinginkan. Untuk lokasi yang sudah ada belum dilakukan evaluasi kembali untuk dinyatakan layak atau tidak untuk dilakukan pemasaran kembali dilokasi tersebut. Informasi ini diperoleh berdasarkan hasil wawancara dengan Yudi Pratama selaku wakil Kepala Bagian Pemasaran di PT. Madubaru PG-PS Madukismo. Oleh karena itu PT. Madubaru ingin membuka cabang untuk mendapatkan hasil yang diinginkan dan melakukan evaluasi terhadap lokasi lama yang sudah menjadi lokasi pemasaran sebelumnya. Akan tetapi PT. Madubaru membutuhkan lokasi yang strategis dengan kriteria lokasi yang tepat. Sehingga dapat memaksimalkan penjualan. Dalam mengoptimalkan hal itu tentu ada berbagai kriteria yang saling berlawanan seperti halnya lokasi yang baik tentunya memiliki harga yang sesuai. Sedangkan dalam memilih lokasi lama ini PT. Madubaru melakukan secara manual. Subjek dalam penelitian ini, adalah aplikasi system pendukung keputusan yang digunakan untuk membantu proses pemilihan lokasi dan evaluasi lokasi lama yang sesuai dengan kriteria-kriteria yang ditetapkan oleh PT. Madubaru. Desain system dengan model proses Modified waterfall. Setelah implementasi selesai, hasil dari system ini, memberikan rekomendasi alternative lokasi yang terbaik serta mengevaluasi lokasi yang sudah ada sehingga dapat diketahui apakah dilajutkan atau tidak lokasi pemasaran tersebut, dengan mengacuh kepada kriteria yang sudah ditentukan dengan menggunakan metode perhitungan AHP. Dari penelitian yang dilakukan menghasilkan perangkat lunak yaitu "Sistem Pendukung Keputusan Pemilihan Lokasi dan Evaluasi lokasi Pemasaran (Gula) Menggunakan Metode AHP” yang dapat digunakan oleh bagian pemasaran PT.Madubaru, untuk menentukan lokasi yang direkomendasikan lokasi terbaik serta mengevaluasi lokasi lama untuk mengetahui apakah dilanjutkan atau tidak sebagai lokasi pemasaran.
\end{abstract}

Kata Kunci : Lokasi Dan Evaluasi, AHP,Sistem Pendukung Keputusan.

\section{PENDAHULUAN}

\subsection{Latar Belakang Masalah}

Langkah awal dalam perencanaan fasilitas adalah penentuan lokasi usaha. Perencanaan lokasi usaha mempunyai peranan yang sangat penting dalam menunjang perkembangan perusahaan dan lokasi usaha menjadi salah satu faktor penentu keberhasilan sebuah pendirian usaha. Namun bukan persoalan yang mudah untuk menentukan suatu usaha akan didirikan. Penentuan lokasi yang tepat akan memberikan sejumlah keuntungan-keuntungan, seperti perusahaan akan berada pada posisi yang kuat dalam persaingan, pengadaan bahan, kemampuan pelayanan terhadap konsumen, dan sebagianya. Sebaliknya kesalahan dalam mengambil keputusan penting dalam penentuan lokasi usaha akan menimbulkan kerugian yang tidak sedikit dengan hilangnya modal yang telah terlanjur ditanam dan ditambahkan investasi untuk mencari lokasi yang baru.

Perusahaan PT. Madubaru yang berlokasi di Daerah Istimewa Yogyakarta bergerak di bidang agro industry dengan memiliki satu pabrik gula dan satu pabrik alkohol dan spiritus, yang dikenal dengan nama PG/PS Madukismo, PT.Madubaru merupakan satu-satunya pabrik gula dan pabrik spiritus di DIY 
yang mengembang tugas untuk mensukseskan program pengadaan pangan nasional khususnya gula pasir dan sebagai perusahaan padat karya, PT.Madubaru juga menampung tenaga kerja dari propinsi DIY. Sebagai perusahaan yang bertanggung jawab dalam pendistribusian produknya. PT. Madubaru mentargetkan penjualan pertahun yaitu 2250 ton untuk setiap lokasi pemasaran. Dalam hal ini adalah gula pasir kemasan, PG/PS Madubaru dituntut untuk dapat menciptakan kinerja pengiriman gula pasir yang handal. Dalam pemenuhan sasaran tersebut ada beberapa kendala yang dihadapi oleh perusahaan yaitu dalam proses pemasaran produk yang dilakukan tidak tercapai target yang diinginkan, data tersebut dilihat pada tahun priode pemasaran 2011-2012 yaitu pada lokasi Kasihan Bantul dan Gedong Kuning, sehingga mengakibatkan pengiriman gula pasir menjadi tidak teratur serta mengakibatkan biaya distribusi yang mahal, Informasi ini diperoleh berdasarkan hasil wawancara dengan Yudi Pratama selaku wakil Kepala Bagian Pemasaran di PT. Madubaru PG-PS Madukismo.

Untuk mengatasi hal tersebut perlu dilakukan pengalokasian distribusi gula pasir curah yang optimal dengan pertimbangan biaya distribusi yang rendah. Selama ini, dalam penentuan lokasi pemasaran gula pasir curah di PT.Madubaru belum terencana, bahkan belum dilakukan evaluasi terhadap lokasi-lokasi yang selama ini menjadi daerah distribusi untuk mengetahui apakah lokasi tersebut layak untuk dilanjutkan penyewaan lokasi atau tidak untuk tahun priode berikutnya.

Untuk menentukan pemilihan lokasi pemasaran produk gula pasir curah pada PT.Madubaru yang optimal, maka diperlukan sebuah sistem yang berfungsi untuk mendukung pengambilan keputusan yang dilakukan oleh perusahaan, untuk itu, saya tertarik untuk melakukan penulisan terhadap penentuan lokasi pemasaran, oleh karena itu, penulis mengambil judul metopen "sistem pendukung keputusan pemilihan lokasi dan evaluasi pemasaran produk (gula pasir curah) pada PT.Madubaru" dengan metode analytical hierarchy process (AHP).

\section{Landasan Teori}

\subsection{Sistem Pendukung Keputusan}

Little (1970), mendefinisikan sistem pendukung keputusan sebagai kumpulan prosedur berbasis model untuk data pemrosesan dan penilaian guna membantu para manajer dalam mengambil keputusan. Dikatakan bahwa supaya sukses sistem harus sederhana, cepat, sehat, mudah dikendalikan, adaptif, lengkap dalam persoalan penting dan mudah untuk didokumentasikan.

Moore dan chang (1980), berpendapat bahwa konsep struktur, seperti banyak disinggung pada awal DSS (bahwa DSS dapat menangani semi terstruktur dan tidak terstruktur), secara umum tidaklah penting. Sebuah masalah dapat dijelaskan sebagai masalah tersetruktur dan tidak terstruktur hanya dengan memperhatikan si pengambilan keputusan atau suatu situasi spesifik (yaini keputusan terstruktur adalah terstruktur karena kita memilih untuk memperlakukan dengan cara seperti itu). [Efraim, Aronson, Peng liang. 2005]

\subsection{AHP (Analytic Hierarchy Process)}

\subsubsection{Pengertian AHP (Analytic Hierarchy Process)}

AHP marupakan suatu model pendukung keputusan yang dikembangkan oleh Thomas L. Saaty. Model pendukung keputusan ini akan menguraikan masalah multi sistem atau multi kriteria yang kompleks menjadi suatu hirarki, menurut Saaty (1993), hirarki didefinisikan sebagai suatu representasi dari sebuah permsalahan yang kompleks dalam suatu struktur multi level dimana level pertama adalah tujuan, yang di ikut level sistem, kriteria, sub sistem dan seterusnya ke bawah hingga level terakhir dari kriteria alternative.

Prinsip-prinsip dasar AHP adalah prinsip yang mendasari logika manusia dalam menganalisa dan memecahkan sebuah masalah. Berikut prinsip-prinsip dalam AHP :

i. Membuat hierarki

Sistem yang kompleks bisa dipahami dengan memecahkan menjadi elemen-elemen pendukung, menyusun elemen secara hierarki, dan menggabungkannya atau mensistensisnya.

ii. Penilaian kriteria dan alteratif

Kriteria dan alternatif dilakukan dengan perbandingan berpasangan. Nilai dan definisi pendapat kwalitatif dari skala perbandingan Saaty bisa diukur menggunakan tabel berikut : 
Tabel 2.3 : Preference Level

\begin{tabular}{|c|l|}
\hline $\begin{array}{c}\text { Intensitas } \\
\text { Kepentingan }\end{array}$ & \multicolumn{1}{c|}{ Keterangan } \\
\hline 1 & Kedua elemen sama pentingnya \\
\hline 3 & Elemen yang satu sedikit lebih penting daripada elemen yang lainnya \\
\hline 5 & Elemen yang satu lebih penting daripada elemen yang lainnya \\
\hline 7 & Satu elemen jelas lebih mutlak penting daripada elemen lainnya \\
\hline 9 & Satu elemen mutlak penting daripada elemen lainnya \\
\hline $2,4,6,8$ & Nilai-nilai antara dua nilai pertimbangan yang berdekatan \\
\hline Kebalikan & $\begin{array}{l}\text { Jika aktivitas i mendapat satu angka dibandingkan dengan aktivitas } \mathrm{j}, \text { maka } \mathrm{j} \\
\text { memiliki nilai kebalikannya dibandingkan dengan } \mathrm{i}\end{array}$ \\
\hline
\end{tabular}

\subsubsection{Perhitungan AHP}

Pada dasarnya, prosedur atau langkah-langkah dalam metode AHP meliputi [6] :

i. Mendefinisikan masalah dan menentukan solusi yang diinginkan, lalu menyusun hierarki dari permasalahan yang dihadapi. Penyusunan hierarki adalah dengan menetapkan tujuan yang merupakan sasaran secara keseluruhan pada level teratas.

ii. Menentuan prioritas elemen

a) Membuat perbandingan pasangan, yaitu membandingkan elemen secara berpasangan sesuai kriteria yang diberikan.

b) Matriks perbandingan diisi dengan menggunakan bilangan untuk mereprentasikan kepentingan relatife dari suatu elemen terhadap elemen yang lain.

iii. Sintesis

Pertimbangan-pertimbangan terhadap perbandingan berpasangan disintesis untuk memperoleh keselurusan prioritas. Hal-hal yang dilakukan dalam langkah ini adalah :

a) Menjumlahkan nilai-nilai dari setiap kolom pada matriks.

b) Membagi setiap nilai dari kolom dengan total kolom yang bersangkutan untuk memperoleh mormalisasi matriks.

c) Menjumlahkan nilai-nilai dari setiap baris dan membaginya dengan jumlah elemen untuk mendapatkan nilai rata-rata.

iv. Mengukur Konsistensi

Dalam membuat keputusan, penting untuk mengetahui seberapa baik konsistensi yang ada. langkahnya adalah sebagai berikur :

a) Kalikan setiap nilai pada kolom pertama dengan prioritas relatif elemen pertama, nilai pada kolom kedua dengan prioritas relatif.

b) Menjumlahkan tiap baris.

c) Hasil dari penjumlahan baris dibagi dengan elemen prioritas relative yang bersangkutan.

d) lalu dapat dihitung lambda ( $\lambda$ ) dengan menjumlahkan hasil bagi dengan banyak elemen yang ada, berikut rumus nya :

$$
\mathrm{CR}-\frac{\mathrm{Cl}}{\mathrm{RT}}
$$

dimana $\mathrm{n}$ adalah jumlah item dari sistem yang dibanding-kan. Setelah mendapatkan consistency index (CI), bisa didapatkan consistency ratio dengan rumus :

$$
C T-{ }_{0}^{1} \text { n }
$$

RI adalah random index yang didapat dari table random index dibawah ini :

Tabel 2.4 : Random Index

\begin{tabular}{|c|c|c|c|c|c|c|c|c|c|c|c|c|c|}
\hline $\mathrm{N}$ & 1,2 & 3 & 4 & 5 & 6 & 7 & 8 & 9 & 10 & 11 & 13 & 14 & 15 \\
\hline $\mathrm{RI}$ & 0.00 & 0.58 & 0.90 & 1.12 & 1.24 & 1.32 & 1.41 & 1.45 & 1.49 & 1,51 & 1,56 & 1,57 & 1,59 \\
\hline
\end{tabular}

Untuk mendapatkan hasil yang konsisten, maka nilai dari consistency ratio (CR) harus lebih kecil sama dengan 0,100. Jika consistency ratio (CR) lebih besar dari 0,100 maka keputusan 
yang diambil harus dievaluasi ulang.

\section{Metode Penelitian}

\subsection{Subjek Penelitian}

Yang menjadi subjek adalah membuat aplikasi sistem penentuan lokasi dan evaluasi lokasi pemasaran. Sistem ini diharapkan dapat membantu dan mempercepat dalam pengambilan keputusan dalam memilih lokasi dan evaluasi lokasi pemasaran . Hasil dari proses sistem akan memberikan keputusan kepada pihak PT.Madubaru khususnya bagian pemasaran dalam pemilihan lokasi dan evaluasi lokasi pemasran lama.

\subsection{Metode Pengumpulan Data}

Adapun metode pengumpulan data yang dilakukan dalam penulisan tugas akhir ini adalah :

1. Studi Pustaka yang berasal dari buku Decision Support Systems and Intelligent Systems dan buku Konsep dan Aplikasi Sistem Pendukung Keputusan yang berkaitan dengan pokok permasalahan yang akan dibahas.

2. Melakukan Observasi ke PT.Madubaru dan lokasi yang akan dijadikan lokasi baru guna memperoleh data-data serta fakta yang berada pada tempat penelitian.

3. Melakukan wawancara dan pemberian kusioner kepada bagian manajer dan stef manajer pemasaran PT.Madubaru.

\section{Hasil Penelitian dan Pembahasan}

\subsection{Analisis Sistem}

\subsubsection{Analisis Proses Bisnis}

Data yang diperlukan pada penelitian ini adalah data lokasi baru dan data lokasi lama untuk di lakukan evaluasi kembali. Penentuan pemilihan lokasi pemasaran baru dilakukan dengan menggunakan beberapa kriteria, yaitu jarak dengan pesaing,luas bangunan, jarak keramaian, jarak perusahaan dan jarak jalan raya. Untuk pengambilan keputusan evaluasi lokasi lama dilakukan dengan kriteria yang berbeda yaitu jangka waktu penyewaan, biaya pengiriman, penyewaan lokasi dan kadaluarsa barang

Sistem melakukan dua tahapan dengan perhitungan metode AHP. Perhitungan tahap satu menghasilkan keputusan pemilihan lokasi baru dan tahapan kedua mehasilkan keputusan evaluasi lokasi lama apakah layak atau tidak untuk dilanjutkan pemasaran lokasi tersebut. Denga cara ini diharapkan dapat menghasilkan hasil akhir yang lebih baik.

\subsubsection{Analisis Kebutuhan Sistem}

Berdasarkan analisis proses bisnis dan data yang diperolah dari PT.Madubaru, didapat spesifikasi kebutuhan sistem sebagai berikut :

1. Sistem mampu melakukan pengolahan data lokasi, data evaluasi lokasi lama, data kriteria lokasi, dan data kriteria evaluasi lokasi lama

2. Sistem dapat memberi keputusan dalam pemilihan lokasi pemasaran yang baru dengan metode AHP.

3. Sistem dapat memberikan keputusan dalam mengevaluasi lokasi lama untuk dinyatakan apakah layak atau tidak layak untuk dilanjutkan lokasi pemasaran

\subsection{Perancangan Sistem}

Adapun perancangan sistem dibagi menjadi :

\subsubsection{Perancangan Proses}

\section{a. Perancangan Alur Sistem}

Alur sistem digambarkan dalam diagram alur (flowchart) sebagai berikut : 


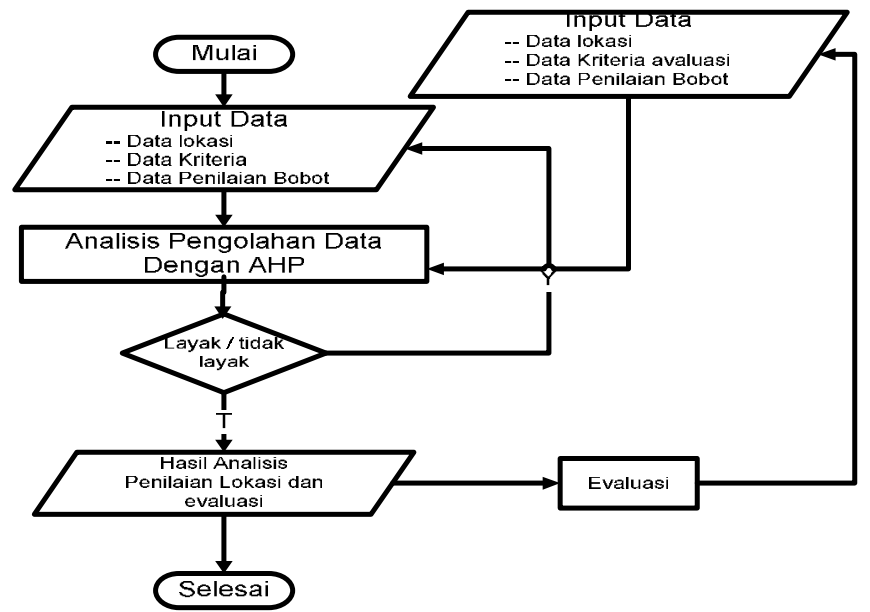

Gambar 4.2 : Flowchart Utama Sistem

\section{b. Diagram Konteks}

Diagram Konteks menggambarkan aliran data antara entitas utama dengan sistem. Pada level ini hanya terdapat satu proses utama yaitu sistem itu sendiri. Berikut gambar diagram konteks :

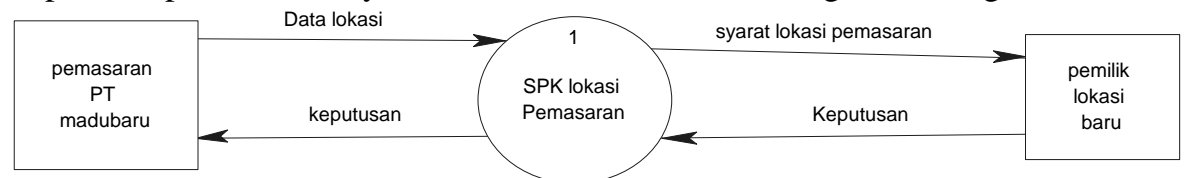

Gambar 4.2 : Diagram Kontek

\subsubsection{Perancangan Basis Data}

Entity Relationship Diagram menggambarkan hubungan antar entitas yang ada dalam sistem. Dari entitas-entitas yang terlibat dapat dibuat suatu diagram hubungan antar entitas sebagai berikut :

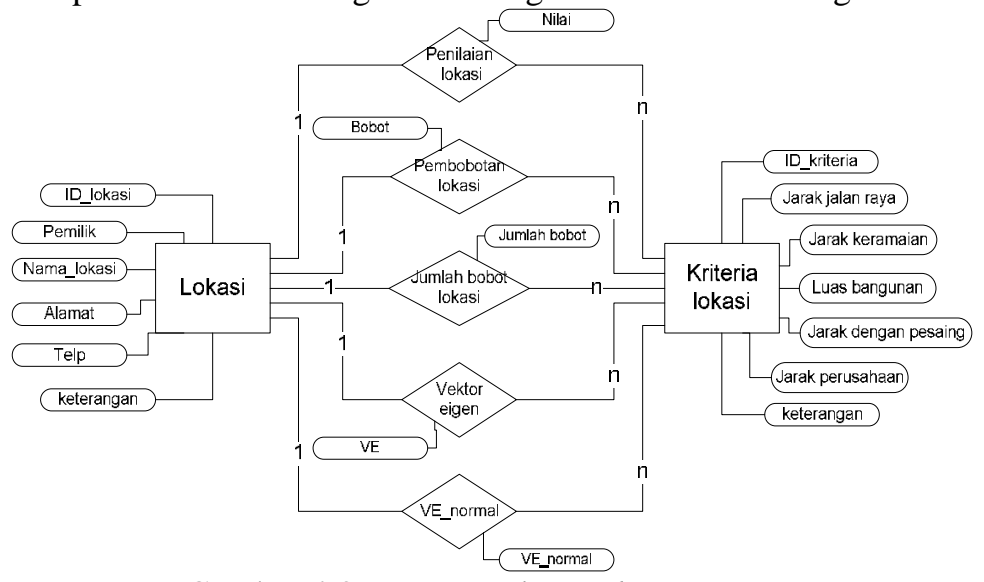

Gambar 4.3 : Entity Relationship Diagram

\subsection{Implementasi}

Berdasarkan desain antarmuka, maka diperoleh hasil implementasi sebagai berikut :

1. Tampilan Form Utama

Pada form utama ini terdapat berbagai menu antara lain menu File, Proses, Laporan, Bantuan, masuk. 


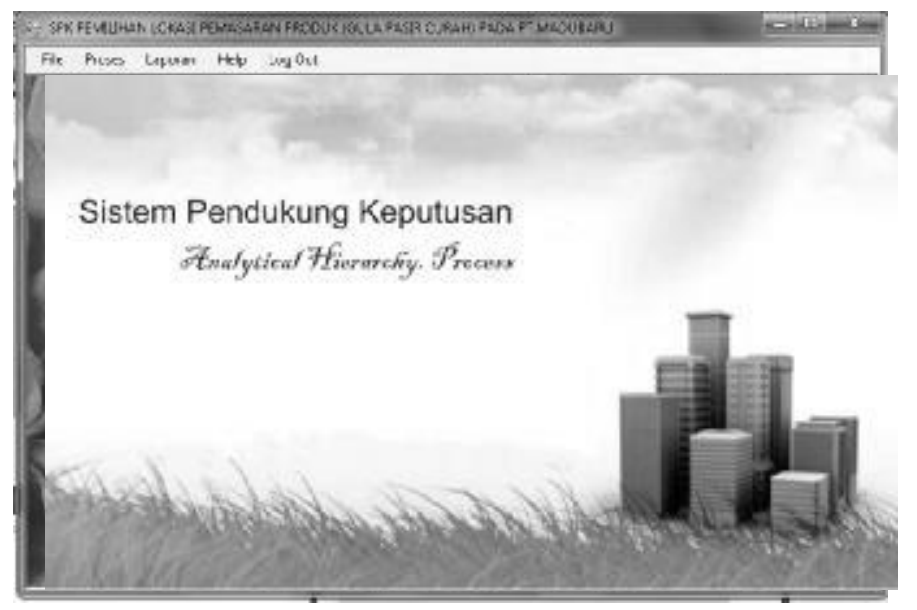

Gambar 4.4 : Tampilan Form Utama

2. Tampilan Form Lokasi dan Form Kriteria

Form Lokasi merupakan form untuk menginputkan data lokasi yang direkomendari untuk dijadikan sebagai lokasi pertimbangan dengan lokasi lain. Form kriteria merupakan form yang digunakan untuk menginputkan nilai kriteria-kriteria yang digunakan untuk melakukan perhitungan AHP. Untuk lebih jelas dapat dilihat pada gambar dibawah ini:

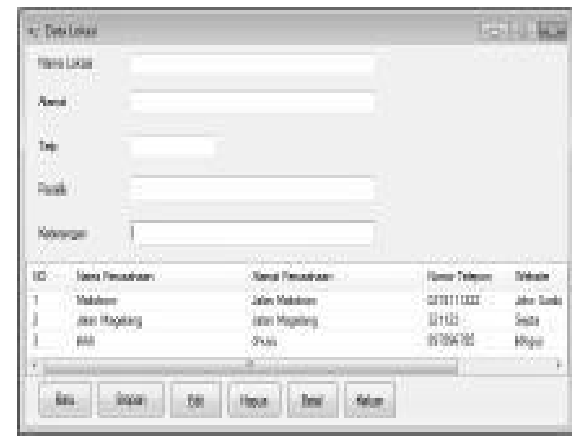

Gambar 4.6 : Tampilan Form Lokasi

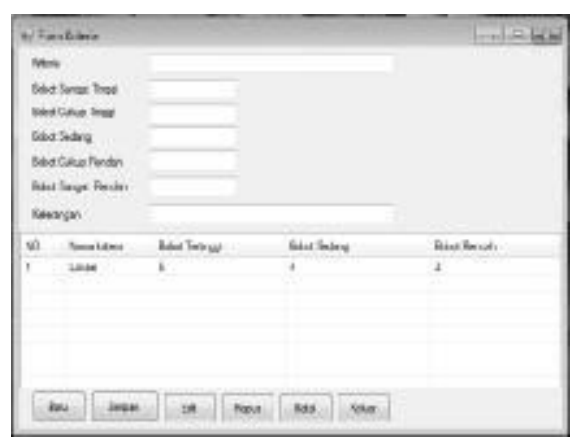

Gambar 4.7 : Tampilan Form Kriteria

3. Tampilan Menu Form perhitungan

Menu perhitungan merupakan fungsi dari perhitungan AHP untuk menentukan keputusan lokasi yang direkomendasikan dan evaluasi lokasi pemasaran untuk layak dilanjutkan atau tidak. Ada bebarapa proses antara lain yaitu pemilihan kriteria, kriteria disederhanakan, VE yang dinormalkan, VE Maksimum, Indek konsisten dan Nilai vektor prioritas.

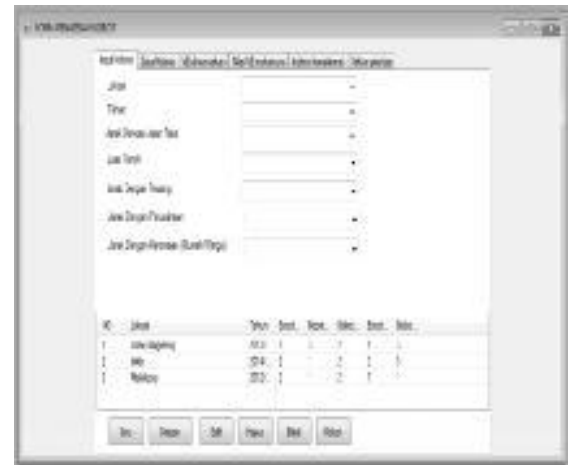

Gambar 4.8 : Tampilan Form pemilihan kriteria lokasi

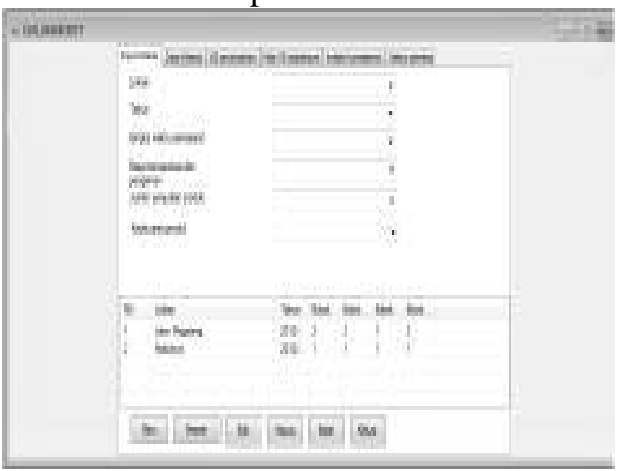

Gambar 4.9 : Tampilan Form 
Evaluasi lokasi lama

4. Tampilan Form kriteria disederhanakan dan form nilai VE Maksimum

Form kriteria yang disederhanakan merupakan tahap awal untuk melakukan penyederhanaan kriteria, untuk form VE Maksimum digunakan untuk mencari nilai maksimum dari data kriteria yang disederhanakan dan nilai Vektor eigen sehinggan didapatlah nilai maksimum.
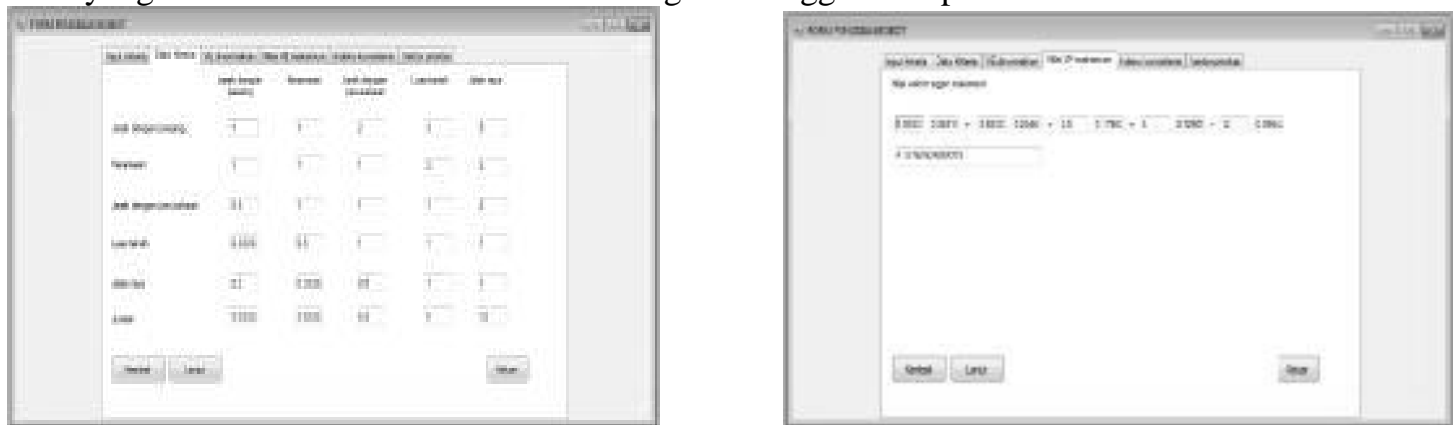

Gambar 4.10 : Tampilan Form kriteria disederhanakan Gambar 4.11 : tampilan form nilai maksimum

5. Tampilan Form indeks konsistensi dan form nilai prioritas

form indeks konsistensi merupakan tahapan untuk mengetahui lokasi itu layak atau tidak untuk dijadikan lokasi dan pemasaran. Untuk form nilai prioritas merupakan tahap akhir dalam perhitungan digunakan untuk membandingkan nilai suatu lokasi dengan lokasi yang lain sehingga dapat dinyatakan lokasi yang paling optimal untuk dijadikan lokasi yang strategis

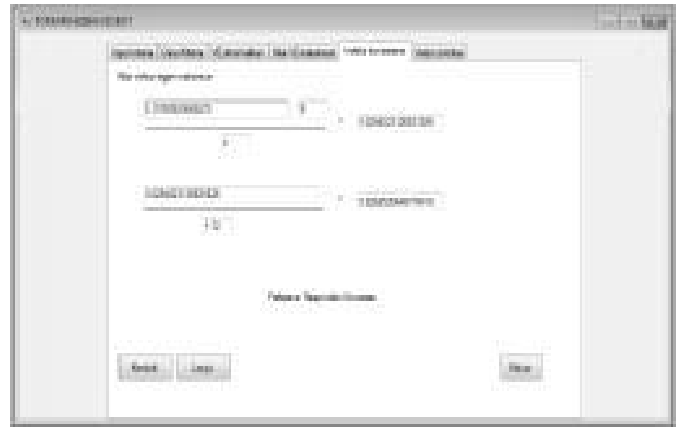

Gambar 4.12 : Tampilan form indeks konsistensi

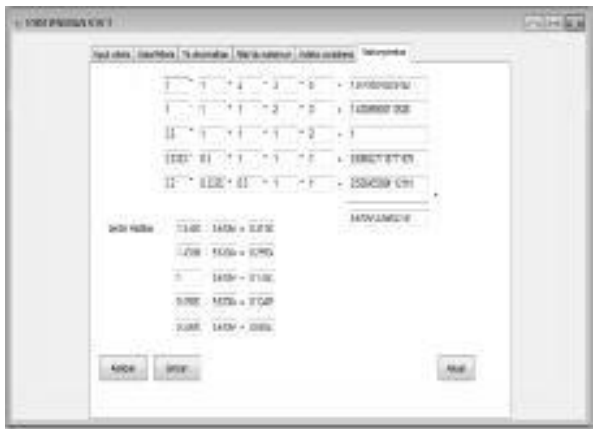

Gambar 4.12 : Tampilan form nilai prioritas

\section{Laporan hasil Perhitungan}

Laporan sistem hasil Perhitungan AHP ada 2 yaitu hasil perhitungan untuk lokasi pemasaran baru berupa nama lokasi, tahun priode, Nilai prioritas dan keterang untuk lokasi yang direkomendasikan atau tidak direkomendasikan dan evaluasi lokasi lama berupa nama lokasi, tahun priode, nilai prioritas dan keterangan apakah layak atau tidak untuk dilajutkan lokasi pemasaran tersebut. 


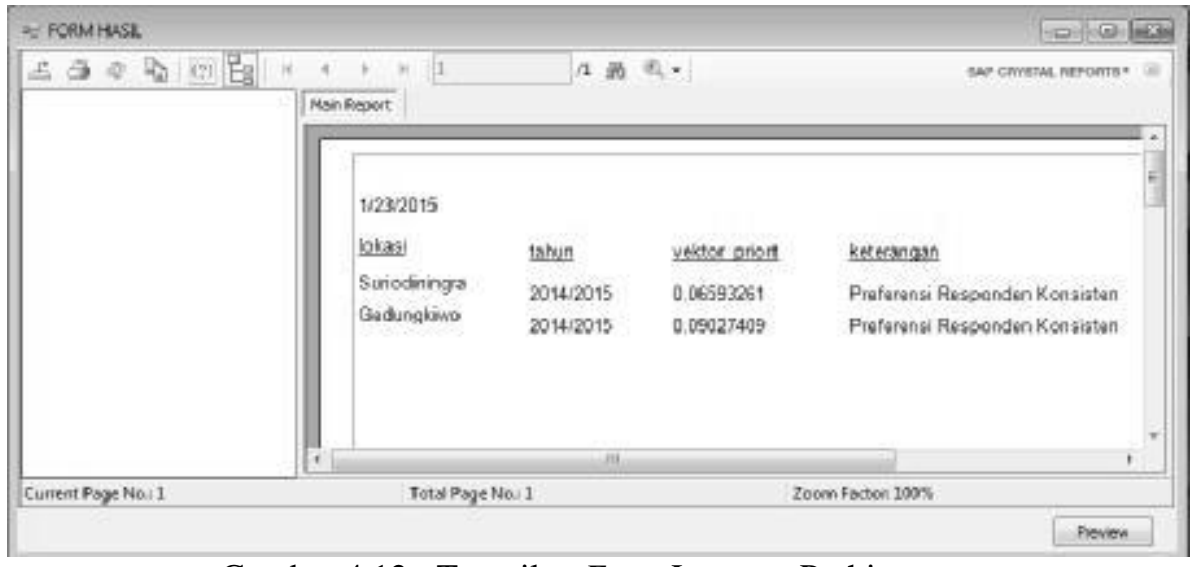

Gambar 4.12 : Tampilan Form Laporan Perhitungan

\subsection{Pengujian Program}

Pada aplikasi ini akan dilakukan pengujian dengan melakukan perhitungan metode AHP terhadap lokasi baru yang direkomendasikan dan lokasi lama untuk dievaluasi kembali serta pengujian black box test dan alpha test.

1. Pengujian studi kasus

Pengujian ini dilakukan dengan melakukan perhitungan terhadap lokasi baru yang telah ditentukan oleh PT.Madubaru untuk dijadikan lokasi pemasaran yang baru. Dari 3 lokasi yang direkomendasikan hanya 2 lokasi yang layak untuk dijadikan lokasi pemasaran dan hanya satu lokasi yang diputuskan untuk dijadikan lokasi pemasaran. Untuk lokasi lama dilakukan perhitungan kembali untuk mengetahui apakah lokasi yang sudah ada bisa dilakukan pemasaran kembali atau tidak, dari 2 lokasi yang diajukan hanya satu lokasi yang layak untuk dilajutkan kembali pemasaran lokasi tersebut.

2. Pengujian black box

Black Box Test merupakan pengujian yang dilakukan untuk mengetahui apakah pemasukan data dan keluaran data sudah sesuai dengan yang diharapkan. Pengujian ini akan dilakukan oleh bagian manajer pemasaran PT.Madubaru dengan memberi selembaran kuisioner

3. Pengujian Aplha test

\section{KESIMPULAN}

Berdasarkan hasil penelitian dan pembahasan, maka dapat disimpulkan bahwa :

Dari hasil uraian mengenai bab-bab sebelumnya dan memperhatikan aplikasi system pendukung keputusan pemilihan lokasi dan evaluasi lokasi pemasaran dengan menggunakan metode $A H P$ maka dapat disimpulkan bahwa :

1. Telah dibuat system pendukung keputusan pemilihan lokasi dan evaluasi lokasi pemasaran produk (gula) dengan metode $A H P$ yang dapat membantu bagi PT.Madubaru khususnya bagian pemasaran untuk pengambilan keputusan dalam memilih lokasi dengan memberikan lokasi alternatif yang terbaik

2. Aplikasi system pendukung keputusan ini telah diuji dan dapat mempermudah dalam proses penentuan lokasi dan evaluasi lokasi pemasaran yang disesuaikan dengan kriteria-kriteria yang ditetapkan oleh bagian manajemen PT.Madubaru

3. Dengan memanfaatkan metode $A H P$ dapat dihasilkan keputusan dengan melihat hasil akhir nilai prioritas dan lokasi itu dapat dinyatakan layat atau tidak dijadikan lokasi pemasaran

4. Dengan mendapatkan lokasi baru dapat juga dilakukan tahap berikutnya yaitu dengan mengevaluasi lokasi tersebut untuk mengetahui apakah lokasi dapat tercapai target yang diinginkan salama melakukan pemasaran. 


\section{DAFTAR PUSTAKA}

[ 1 ] Denny., 2007. "Sistem Pendukung Keputusan Pemilihan Lokasi Dealer Sepeda Motor Dengan Metode Promether", Skripsi S-1, Universitas Gadjah Mada, Yogyakarta

[2 ] Alecia Joostenz, Sanny., 2011 "Sistem pendukung Keputusan Pemilihan Lokasi Perumahan Dengan Metode Fuzzy Pada PT.Adi Gunawan Saputra Palembang', Skripsi S-1, STMIK, Palembang.

[ 3 ] Winiarti, Sri., 2007, "Diktat Kuliah Sistem Informasi”, Universitas Ahmad Dahlan, Yogyakarta.

[ 4 ] Kadir, Abdul. "Pengenalan Sistem Informasi", Yogyakarta, Andi.

[ 5 ] Kusrini., 2007. "Konsep Dan Aplikasi Sistem Pendukung Keputusan”, Yogyakarta, Andi.

[ 6 ] Efraim., Aronson., peng liang., 2005. "Decision support Systems and Intelligent Systems", Yogyakarta, Andi.

[ 7 ] Ladjamudin bin AL Bahra., 2006. "Rekaya perangkat lunak”, Yogyakarta, Graha Ilmu.

[ 8 ] Andrianto., 2010. "Analisis dan Perancangan Sistem Pendukung Keputusan Distribusi Alat-alat Kesehatan menggunakan Metode Max-Min ( Studi Kasus Klinik Kardiovaskular Hospital Cinere)", Skripsi S1, Universitas Pembangunan Nasional, Jakarta. 